\title{
Blockholder Heterogeneity and Conflicts in Cross-border Acquisitions
}

Chen, Victor Zitian; Hobdari, Bersant; Zhang, Yilei

\author{
Document Version \\ Accepted author manuscript \\ Published in: \\ Journal of Corporate Finance \\ DOI: \\ 10.1016/j.jcorpfin.2018.02.002 \\ Publication date: \\ 2019 \\ License \\ CC BY-NC-ND
}

Citation for published version (APA):

Chen, V. Z., Hobdari, B., \& Zhang, Y. (2019). Blockholder Heterogeneity and Conflicts in Cross-border Acquisitions. Journal of Corporate Finance, 57, 86-101. https://doi.org/10.1016/j.jcorpfin.2018.02.002

Link to publication in CBS Research Portal

\section{General rights}

Copyright and moral rights for the publications made accessible in the public portal are retained by the authors and/or other copyright owners and it is a condition of accessing publications that users recognise and abide by the legal requirements associated with these rights.

\section{Take down policy}

If you believe that this document breaches copyright please contact us (research.lib@cbs.dk) providing details, and we will remove access to the work immediately and investigate your claim.

Download date: 26. Apr. 2023

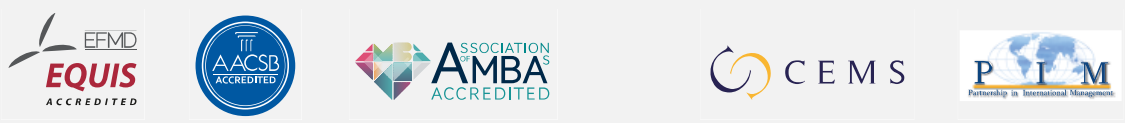




\title{
Blockholder Heterogeneity and Conflicts in Cross-border Acquisitions
}

\author{
Victor Zitian Chen, Bersant Hobdari, and Yilei Zhang
}

Journal article (Accepted manuscript*)

\section{Please cite this article as:}

Chen, V. Z., Hobdari, B., \& Zhang, Y. (2019). Blockholder Heterogeneity and Conflicts in Cross-border Acquisitions. Journal of Corporate Finance, 57(August), 86-101.

https://doi.org/10.1016/j.jcorpfin.2018.02.002

001: 10.1016/j.jcorpfin.2018.02.002

* This version of the article has been accepted for publication and undergone full peer review but has not been through the copyediting, typesetting, pagination and proofreading process, which may lead to differences between this version and the publisher's final version AKA Version of Record.

Uploaded to CBS Research Portal: August 2019

(C) 2019. This manuscript version is made available under the CC-BY-NC-ND 4.0 license http://creativecommons.org/licenses/by-nc-nd/4.0/ 


\title{
Blockholder Heterogeneity and Conflicts in Cross-border Acquisitions
}

\author{
Victor Zitian Chen \\ Belk College of Business \\ University of North Carolina at Charlotte \\ 9201 University City Blvd \\ Charlotte, NC 28223 \\ Email: zchen@uncc.edu \\ *Corresponding author \\ Bersant Hobdari \\ Department of International Management and Economics \\ Copenhagen Business School
}

Yilei Zhang

Belk College of Business

University of North Carolina at Charlotte

\section{Accepted by Journal of Corporate Finance}

Special Issue on "Corporate Governance of a Multinational Enterprise" 


\title{
Blockholder Heterogeneity and Conflicts in Cross-border Acquisitions
}

\begin{abstract}
We investigate the principal-principal (PP) conflicts between large blockholders in the context of cross-border acquisitions (CBAs). We focus on the conflicts between family blockholders and two groups of financial institutional investors - banks and mutual funds. We hypothesize that different types of blockholders have heterogeneous preferences with respect to the CBA decision and outcomes. We suggest that the PP conflicts in CBA differ across the blockholders. Banks are pressure sensitive and cooperative with the management because of their clientele relationship with firms, while mutual funds are subject to more financial scrutiny and independent from the management, making them pressure resistant. When in conflict with more powerful family blockholders, mutual funds will choose to exit after a CBA decision, whereas banks are more likely to stay. With an equally distributed voting power, family and mutual fund blockholders will be more motivated to monitor over each other and jointly discipline the management, leading to more careful selection of CBAs and higher overall shareholder value. However, such effects are weak in the case of family and banks. We find support for these conjectures using data on CBAs undertaken by US public firms over the period 2003-2016.
\end{abstract}

JEL classification: G32, G34

Keywords: Cross-border mergers and acquisitions, Principal-principal conflicts, Blockholders 


\section{Introduction}

International business research has largely focused on strategies of multinational enterprises (MNEs) in expanding their activities across borders. These activities generate more governance complexities than domestic operations. It is important to understand the ownership and control structures in MNEs and how different conflicts of interests and governance mechanisms impact strategic choices (Filatotchev and Wright, 2011). Agency theories of the principal-agent (PA) conflicts and principle-principal (PP) conflicts suggest that corporate policies are affected by the power balance between management and controlling shareholders. ${ }^{1}$ The goals of an MNE may reflect primarily managerial incentives such as overexpansion due to management's self-interest or their hubris, when ownership is diffused (Haleblian et al., 2009; Hayward and Hambrick, 1997; Seth et al., 2000; Seth et al., 2002), or the controlling shareholder's objective function, when ownership is concentrated (André et al., 2014; Caprio et al., 2011; Miller et al., 2010).

Within the PP conflict framework, an emerging literature explores the diverging interests among multiple large blockholders and their potential impacts. However, current studies on the preferences of certain types of blockholders do not fully address the effects of the conflicts of interests of blockholders on a firm's policy decisions such as international expansion. Drawing on the literature on multiple blockholder structures (Attig et al., 2009; Edmans and Manso, 2011; Maury and Pajuste, 2005), we seek to partially fill this gap by analyzing the PP conflicts between blockholders with different objectives in the context of an MNE's cross-border acquisitions (CBAs). Specifically, we investigate blockholder heterogeneity and conflicts in CBAs, and how

\footnotetext{
1 The PA conflicts between shareholders and management arise from the separation of ownership and control (Fama and Jensen, 1983; Jensen and Meckling, 1976). The PP conflicts are driven by private benefits of the large shareholders who expropriate minority shareholders' financial interests (Goranova and Zajac, 2015; Morck et al., 2005).
} 
they affect CBA decisions and overall shareholder wealth effect.

We focus especially on the conflicts between family shareholders and financial institutional investors due to their likely divergent objective functions (Maury and Pajuste, 2005; Morck et al., 2005; Shleifer and Vishny, 1997). We further distinguish institutional investors between pressure-sensitive financial blockholders, such as banks, and pressure-resistant financial blockholders, such as mutual funds, based on existing or potential clientele relationships with the focal firm (Brickley et al., 1988; Brossard et al., 2013; Chowdhury and Wang, 2009; Thomsen and Pedersen, 2000). The potential business opportunities are expected to be rich in a large-scaled and complex international acquisition for banks to arrange financing and offer consulting services. Whereas, with revenue coming solely from the equity holding, pressure-resistant financial blockholders are relatively less subject to management influence and thus more selective in CBA projects.

Financial institutional investors exercise their ownership rights through two channels influencing with voice (e.g., through board representation) or voting with feet. As pressure-resistant investors, we expect mutual funds will choose to scale down their investment in response to a CBA associated with high family ownership because it is costly to coordinate with a powerful blockholder who has conflicting objectives. However, when the competing groups have relatively even voting power, they will have the incentive and capability to negotiate with each other, monitor each other and jointly monitor the management, leading to more careful selection of CBAs by the management and larger benefit to shareholders. On the contrary, we expect to find less influence and overall effect by pressure-sensitive institutional investors such as banks.

Our conjectures are supported by tests based on a sample of 2,752 cross-border deals 
announced by US public firms over 2003 to 2016. First, we find that family blockholding of voting rights is significantly negatively related to the likelihood of a CBA; whereas bank ownership is positively related with CBA likelihood and the impact of mutual fund ownership is insignificant. Second, conditioning on a CBA decision being made, we find that mutual funds tend to withdraw their investment when family ownership is high. Lastly, by regressing three-day cumulative abnormal returns (CARs) around CBA announcement on the ownership differences between blockholders, we find that the balance of power between family and mutual fund blockholdings leads to higher overall shareholder value compared to the situations when either party has a dominant position. As expected, such evidence regarding bank blockholding is insignificant.

Our paper makes important contributions to the corporate governance and international business literature. First, we examine a new type of conflicts focusing on heterogeneous preferences of different types of blockholders. This perspective on blockholder heterogeneity cast new light on the relation between corporate governance and MNE strategic choices, which is not adequately addressed by the traditional agency theory. Second, blockholder heterogeneity leads to the important question on the effect of the relative influence among various types of blockholders. To our knowledge, we are the first to study how the distribution of voting power among blockholders affects a firm's monitoring mechanisms and overall shareholder wealth. We propose that equally distributed power between competing blockholders generates the most effective monitoring effects and enhances firm value. We believe this line of research is important and warrants more future studies.

The remainder of the paper is organized as follows. Section 2 develops the theoretical arguments and outline hypotheses. Section 3 introduces the sample and discusses the variables. 
Section 4 reports empirical results. Section 5 concludes with a discussion of our findings.

\section{Theory and Hypotheses}

CBA is an important strategic decision for MNEs where blockholders heterogeneity and conflicts are explicitly exposed in the decision process. First, the CEO often needs to consult with large shareholders on important corporate policies through the board of directors (Becht et al., 2016). Therefore, CBA decision usually involves blockholders and may reflect how blockholders interact. Second, international operations involve large amounts of uncertainties and additional risks, including complexities from monitoring and communication, the risks of country default and exchange rate fluctuations (Eaton et al., 1986; Mantecon, 2009). The additional challenges would trigger different expectations from blockholders on the optimal financial returns and risks, and thus lead to blockholder conflicts. Third, CBAs are an international boundary spanning from the familiar zones in the home market to a less familiar and foreign market, to which different blockholders may display different preferences and tolerance (Greenberg et al., 2005). Therefore, CBAs offer an ideal context to study the theory of blockholder PP conflicts.

\subsection{Blockholder Heterogeneity and CBAs}

Among blockholder types, family blockholders hold distinctive objectives that may diverge from shareholder (financial) value maximization (Habbershon and Williams, 1999; Sluhan, 2016). Family blockholders are motivated to preserve and advance their own non-financial private benefits of control (Kontinen and Ojala, 2010; Pukall and Calabrò, 2014). Such non-financial benefits include family control and influence, family identification with the 
firm, social ties, emotional attachments, and renewal of family bonds, often collectively referred to as socioemotional wealth (Berrone et al., 2010). In addition, they typically hold an undiversified or closely correlated portfolio of businesses within a family's comfort zone (Miller et al., 2010). Accordingly, family blockholders engage in fewer risky projects primarily as a strategy to preserve both core values and wealth in their family business for intergenerational continuity (Anderson and Reeb, 2003; Anderson et al., 2012; Gomez-Mejia et al., 2015; Gomez-Mejia et al., 2010; Ward, 2004) or only take risks for loss aversion of nonfinancial private benefits of control (Berrone et al., 2010).

When it comes to international investments, family MNEs tend to be relatively conservative (Berrone et al., 2012; Gomez-Mejia et al., 2015). Concerned about family socioemotional wealth, family-owned firms are found to focus on domestic or nearby operations (Banalieva and Eddleston, 2011), and tend to worry about dilution of voting power in large-scale acquisitions and risks of managing a new parent-subsidiary relationship (Boellis et al., 2016; Caprio et al., 2011). Even when they support a CBA, they would be more comfortable with smaller transactions. While there is mixed evidence from dispersed studies, the overall findings generally support a conservative behavior of family firms in international expansions. For instance, a meta-analysis (van Essen et al., 2010) based on US listed firms finds that family firms in general are less internationalized than non-family firms. Using cross-national samples, another meta-analysis (Arregle et al., 2017) similarly suggests that family firms are less internationalized than nonfamily firms, and that family-controlled firms are strongly less internationalized than nonfamily-controlled firms. Following these theoretical arguments and empirical evidence, we expect that family as a blockholder is generally less active in CBA activities in terms of propensity and deal value. 
Institutional investors as blockholders, unlike families, are driven primarily by financial returns and tend to be more diversified and more prone to taking risks than family blockholders (Lien and Filatotchev, 2015; Wright et al., 1996). Therefore, they are more inclined to undertake risky projects such as CBAs as long as such risks are compensated by financial returns. However, institutional investors may differ in their support of CBAs due to different public scrutiny and clientele relationships with the investing firm. We distinguish between two different types of institutional investors: mutual funds and banks. First, under the federal laws and SEC regulations, mutual funds are subject to perhaps the most extensive disclosure. They are required to report their voting decisions on proxies, subjecting their decisions to public scrutiny by minority investors, which motivates them to stay financially disciplined, and actively monitor and intervene in the managerial decision process to ensure value creation (Iliev and Lowry, 2015; Morgan et al., 2011). Therefore, mutual funds are more selective in choosing only value-creating CBAs, limiting their propensity and scale of international acquisitions.

Second, an important difference between mutual funds and banks is the clientele relationship with the management, which affects the willingness to monitor and intervene in managerial decisions on $\mathrm{CBA}$ projects. As documented in the literature, institutional investors can be categorized as "pressure-sensitive" and "pressure-resistant" (Brickley et al., 1988; Brossard et al., 2013; Daily et al., 2003; Dalton et al., 2003). Pressure-sensitive institutions, such as banks, have regular business with the firm. They are found to be more subject to management influence than pressure-resistant institutions, and are reluctant to challenge management decisions in order to maintain their existing or explore potential business with the firm. This distinction has been widely discussed and tested in finance (Brickley et al., 1988; Brossard et al., 2013) and management studies (David et al., 1998; David and Kochhar, 1996; Tihanyi et al., 
2003; Zahra et al., 2000). For instance, it is found that ownership by pressure-sensitive institutions is associated with more pronounced agency problems as evidenced in the CEO compensation policy (David et al., 1998).

Applying this logic to CBA, as blockholders of their existing or potential clients, banks play the role of position holder to create, enhance and support the clientele relationship, along with their general equity investor role. Their non-equity businesses such as consulting, auditing, and financial services in CBAs can generate additional revenues for banks, while providing, in turn, necessary support for firms to undertake large investments like CBAs. For these reasons, higher bank blockholding indicates higher collaboration between banks and management. Such collaboration may help promote CBAs, leading to a positive relation between bank blockholding and CBA likelihood.

In contrast, mutual funds do not have clientele relationships with their portfolio firms and thus are focused primarily on value maximization of the firm, often under the guidance of professional investment advisors or proxy companies (Brickley et al., 1988; Brossard et al., 2013; Thomsen and Pedersen, 2000). Unlike family blockholders, mutual funds do not oppose CBAs for loss aversion underlying socioemotional wealth reasons, and are more willing to support CBAs that fit in their portfolio agenda. However, compared to banks, they are more selective in CBA projects. With higher ownership, mutual funds can provide support for firms to engage in CBAs or impose discipline on management decisions to reject CBAs that are not in their interest. ${ }^{2}$ The two effects tend to offset each other leading to either a weaker or insignificant relation between mutual fund blockholding and CBA propensity.

\footnotetext{
${ }^{2}$ This is accomplished though a twofold mechanism. In addition to regular blockholder monitoring (i.e., "vote with hands"), their option to "vote with feet" adds additional ex ante managerial discipline, because large scale selling by blockholders would convey negative information to the market which negatively affects firm value and CEO compensation (Bharath et al., 2013; Edmans and Manso, 2011; Helwege et al., 2012; Parrino et al., 2003).
} 
Summarizing the above arguments, we hypothesize that,

H1a. The proportion of voting rights held by a family blockholder is negatively related to CBA propensity and transaction value.

H1b. The proportion of voting rights held by bank blockholders is positively related to CBA propensity and transaction value; with the relationship being weaker or insignificant for mutual fund blockholders.

\subsection{Blockholder PP Conflicts and Activities after a CBA decision}

As discussed above, family owner might prioritize private benefits of control that may conflict with financial institutional investors, which focus on value creation, professional management, and relatively short- or medium-term holding to cash out returns. As a consequence, family owners and financial institutional blockholders may act as conflicting groups, as they seek more influence over the firm and pressure the manager to pursue policies fitting their own preferences.

From a governance perspective, blockholders are considered an effective monitoring mechanism, as they have the ability to influence management through either their voting rights (D'Mello et al., 2011) or through informed trading of their shares (Edmans, 2014). While both "vote-with-hand" and "vote-with-feet" have been previously analyzed at the level of individual blockholders or different types of blockholders separately (Edmans and Manso, 2011), it is important to consider them jointly in the presence of multiple blockholder groups, because of potential coalition formation based on similar identities and preferences.

Traditional agency theory suggests that blockholders are more motivated to, for instance, initiate shareholder-sponsored meetings and private negotiations, when they have relatively more 
concentrated control in the firm (Fama and Jensen, 1983; Jensen and Meckling, 1976). However, when they have a relatively smaller block of holdings, and thus are dominated by the voting power of other blockholders, they may choose exit as a more efficient strategy (Edmans and Manso, 2011). The reason is that it becomes difficult and costly to coordinate with other powerful blockholders, who may not share the same objectives and may not accept each other's motives. Consistent with this argument, Duan and Jiao (2016) find that mutual funds with smaller block of equity are more likely to exit than a concentrated block when they disagree with a corporate decision.

In the context of CBA, to some extent the ex post "exit" reflects the PP conflicts between blockholders. Since banks are relatively passive and collaborative in CBA decisions, we expect the conflicts of interest to be mainly between mutual funds and family. Holding everything else constant, a CBA decision in a firm with high family ownership is likely to be influenced more by the family blockholder's preferences, which conflicts the financial-oriented agenda of mutual funds. With short-term financial pressures and liquidity needs from their investors (Sherman et al., 1998), mutual funds are more likely to reduce or eliminate their ownership in a firm when CBA decisions are more likely to be influenced by family. After all, secondary market trading is more efficient and faster than negotiating with a more powerful family blockholder and management (Edmans, 2014; Edmans and Manso, 2011). Since blockholding of voting rights is a proxy of a blockholder's influence, we suggest that a higher blockholding by the family at the time of CBAs may suggest the CBA decisions are more aligned with the family's agenda, causing distrust and thus exit of mutual funds.

In contrast, holding their blockholder position is valuable to banks to create or enhance a clientele relationship with the firm. In addition, banks may benefit from CBAs for non-equity 
business income. Therefore, they may not choose to exit after a CBA decision even when it's more likely that the decision is associated with family agenda under a high family ownership.

This brings our next hypothesis as follows:

H2. After a CBA announcement, mutual fund blockholders will reduce or eliminate their holdings in response to a high family ownership. In contrast, bank blockholders are less likely to do so.

\subsection{Blockholder PP Conflicts and Shareholder Value Creation}

The extant literature on shareholder types and firm performance focuses on impacts of different types of blockholders separately (Chen et al., 2010; Ferreira et al., 2010), rather than more directly testing the impact of voting power balance of co-existing blockholders. This overlooks the impact of PP conflicts on shareholder wealth when there are multiple types of conflicting blockholders contesting against each other (Attig et al., 2009; Edmans and Manso, 2011; Maury and Pajuste, 2005). Building on our discussion of the different blockholder preferences and PP conflicts in CBAs, we examine the effects of differences in voting rights between the family blockholder and institutional investors on shareholder value effects of CBAs.

When there are multiple types of blockholders with conflicting interests, if one blockholder has a dominating ownership, the other blockholder(s) may have to stay silent or choose to exit (as argued in $\mathrm{H} 2$ ). This leaves the monitoring role only played by one blockholder whose interest is not necessarily fully in line with overall shareholders. When conflicting blockholders have relatively equal voting rights, they will have the incentive as well as capability to actively monitor each other, and also be motivated to have active communications with the management, which jointly discipline the management. This leads to a two-tier monitoring 
system: monitoring among blockholders over each other and joint monitoring on the management. We expect this system is most effective to reduce agency costs and benefit overall shareholders.

The implication is that a balanced power among multiple blockholders will lead to better firm performance and shareholder value. Recent empirical studies on multiple blockholder structures have provided consistent evidence supporting this implication in various geographic settings. For example, Maury and Pajuste (2005) find that an equal distribution of votes among large blockholders in Finnish listed firms has a positive effect on firm value. Attig et al. (2009) find that the coexistence of multiple large shareholders in listed firms from nine East Asian economies is associated with a significant valuation premium. None of these efforts, however, have examined the performance effects of a firm's strategic policy under PP conflicts or clearly theorized the consequences of different pairs of shareholder types.

Following these arguments, we suggest that CBA value creation will depend on the distribution of voting power between conflicting blockholders such as mutual funds and family. As discussed earlier, mutual funds and families tend to have conflicting agenda in CBA. When there is an evenly distributed voting power, both types of blockholders may become more motivated to negotiate and hold each other accountable through more active communication with the management. Under constant contests and joint scrutiny of two conflicting blockholder groups, managers would find it relatively more difficult to pursue their self-interests, leading to more careful selection of value-enhancing CBAs and thus overall shareholder value effects. For similar reasons as discussed earlier, we do not expect to see such effects between pressure-sensitive institutional investors as banks and family.

Combining these arguments, we hypothesize: 
H3. An equal distribution of voting shares between mutual fund and family blockholders leads to a higher CBA performance, compared to the dominant control of voting shares by either blockholder group. In contrast, the ownership difference between banks and family does not have significant effect on CBA performance.

\section{Data and Empirical Design}

Large block ownership is quite widespread in US public corporations. ${ }^{3}$ In a random sample of US public firms, Holderness (2009) shows that $96 \%$ of firms have at least one blockholder, defined as a shareholder owning more than $5 \%$ of outstanding shares. Further, blockholders are quite heterogeneous, including individuals (40\%), mutual funds (32\%), financial institutions (10\%), venture capitalists (4\%), pension funds (4\%) and other corporations $(7 \%)$.

We obtain ownership data of US public firms from Bureau van Dijk (BvD)'s ORBIS database over the period 2002 to 2016 . ORBIS provides detailed information on the type of shareholders, as well as their direct and total voting (or control) rights. Blockholders are identified as shareholder with at least 5\% voting rights of each firm (Holderness, 2009). To measure the control and influential power of blockholders, we calculate the relative ownership variable as the voting shares directly and indirectly owned by each blockholder as a proportion of total voting shares owned by all blockholders (Black and Coffee, 1994; Chung and Kim, 1999; Crespi and Renneboog, 2010). ${ }^{4}$ To analyze heterogeneous incentives and conflicts of interests of

\footnotetext{
${ }^{3}$ There is no common definition of what constitutes a blockholder. Most of the literature focuses on the percentage of shares held by a block, an approach that we also adopt in this paper. However, conceptually, the dollar value of shares held by a blockholder could also be important (Edmans and Manso, 2011).

4 Suppose blockholders A and B each owns $10 \%$ of firm XYZ directly; and at the same time A owns 50\% directly of $\mathrm{B}$. Then $\mathrm{A}$ has $10 \%$ direct voting rights of $\mathrm{XYZ}$ and $15 \%$ (i.e., $10 \%+50 \% \times 10 \%$ ) total voting rights of $\mathrm{XYZ}$. For $\mathrm{B}$, both the direct and total voting rights of $\mathrm{XYZ}$ are $10 \%$. If the total voting shares owned by all blockholders of
} 
different blockholders, we focus on three groups: families and individuals, banks as representative of pressure-sensitive institutional investors, ${ }^{5}$ and mutual funds as representative of pressure-resistant institutional investors.

CBAs by US public firms are obtained from BvD's Zephyr Merger and Acquisition database (Zephyr thereafter). We choose Zephyr to generate our merger sample because it uses the same BvD firm identifier as ORBIS, which allows us to match M\&A data with blockholding data. Following the literature (for example, Dikova and Sahib, 2013; John et al., 2015; Moeller et al., 2005), we focus on complete deals and require the acquiring firm controls less than $50 \%$ of the shares of the target firm before the announcement, and ends up with greater than $50 \%$ shares of the target when the deal closes. We also require CBAs to have non-missing target country information, and at least 10 deals in each target country over the sample period. Deals in low tax regimes (where effective corporate tax rate is less than 10\%), and deals where either acquirer or target are finance firms (SIC code between 6000 to 6999) or regulated utilities (SIC code between 4900 to 4999) are excluded. We require deals to have ORBIS ownership data in the year immediately before the merger announcement date to be included. We obtain major firm characteristic variables from Compustat, and stock return data from CRSP. Our final sample includes 2,752 cross border deals announced over 2003 to 2016 by 863 firms.

Insert Table 1 about here

$\mathrm{XYZ}$ is $60 \%$ (note this can be greater than $100 \%$ as we count both the direct and indirect blockholdings), then the ownership of $\mathrm{A}$ is $25 \%$ (i.e., $15 \%$ / 60\%) and the ownership of B is $16.67 \%$ (i.e., $10 \% / 60 \%$ ).

5 ORBIS dataset does not separate commercial bank and investment bank blockholdings. However, it is rare in the U.S. for commercial banks to invest in common stocks due to regulatory restriction, although they have ways to do it indirectly (e.g., through a holding company). Some earlier studies typically would include insurance companies as pressure-sensitive investors (Brickley et al., 1988). In our sample, the mean of insurance blockholdings in our sample is about $1.5 \%$, with the $95^{\text {th }}$ percentile and below being $0 \%$. Therefore, we do not include insurance companies to avoid potential outlier effects driven by the paucity of insurance company blockholders. 
Table 1 reports the sample distribution by announcement year and by target country. Our sample cross-border deals span 14 years. There is a clustering of deals in some years, and we control for year fixed effects in all multivariate analyses. The cross-border target firms cover 33 countries with United Kingdom, Canada, and Germany the top three countries. To account for the effects of different economic and cultural environments of target firms, we also use country fixed effect.

Insert Table 2 about here

Table 2 reports the summary statistics and a correlation matrix of main variables. Details of the variable definitions are provided in the Appendix. All the ownership and firm characteristic variables are measured at the fiscal year immediately before the merger announcement date. The sample cross-border acquirers on average have block voting shares of $33.5 \%$ owned by banks, $18.6 \%$ owned by mutual funds and $8.1 \%$ owned by families. Using family ownership as the benchmark, we calculate the block voting ownership difference between banks and family, as well as the ownership difference between mutual funds and family. Note that a smaller difference indicates a closer match in power. Our sample cross-border acquirers have a mean ownership difference between banks and family blockholders of $25 \%$ and a mean ownership difference between mutual fund and family blockholders of $10 \%$. The four dummy variables defined based on the ownership differences show that $14 \%$ of acquirers have less than $5 \%$ ownership difference between banks or mutual funds and families; $70 \%$ (52\%) of acquirers have greater than 5\% ownership difference between banks (mutual funds) and families.

To measure the size of CBAs, we sum up the deal value of all CBAs by a firm within a 
fiscal year. Due to the missing data on deal value in Zephyr, we are able to get deal value for 1,034 deal-year observations. We take the logarithm of deal value to smooth extreme values. We use the change of bank ownership and mutual fund ownership to examine the blockholder's "voting with feet" activity. The changes are calculated from the year immediately before the announcement to the year after the announcement. We calculate both the change of blockholdings and the change of the number of blockholders of banks and mutual funds. On average, the change of ownership by banks around CBAs is trivial. The change of mutual fund ownership, on the other hand, is $2.3 \%$ on average. This evidence is consistent with the argument that banks are relatively inactive shareholders while mutual funds are more active.

To measure the overall shareholder wealth effect of CBAs, we calculate the three-day market model-adjusted cumulative abnormal returns (CARs) over days $[-1,+1]$ where day 0 is the announcement day. The market model parameters are estimated over the period $(-210,-11)$ with the CRSP value-weighted return as the market index. The mean (median) of the three-day CARs of our sample cross-border deals is $0.5 \%(0.3 \%){ }^{6}$

Main firm characteristic variables include firm size (logarithm of total assets), growth opportunities (market-to-book ratio), leverage, and cash ratio. We use foreign sales to total firm sales as the instrument variable in the $1^{\text {st }}$ stage Probit model of a firm's CBA choice; ${ }^{7}$ and expect MNEs with foreign operations are more likely to engage in CBA activities. We construct deal characteristics using available information provided by Zephyr. We find that $53 \%$ of cross-border deals are diversifying acquisitions where acquirer and target firms are in different Fama-French

\footnotetext{
${ }^{6}$ Moeller and Schlingemann (2005) show the average CARs for CBAs by US public firms is $0.3 \%$ over 1985-1995. Francis et al. (2008) document mean CARs of $0.96 \%$ over 1990-2003. Our sample is different as we require ownership data, and also different in terms of sample period. Nevertheless, our CAR value is quite similar to that reported in the literature.

${ }^{7}$ Foreign sales result from the sale of goods and services produced outside the U.S. (e.g., a U.S. firm with a manufacturing facility in Europe). The goods and services may be sold in the U.S. (i.e., domestically), in the foreign country where they are produced, or in another country.
} 
49 industry categories; ${ }^{8} 24 \%$ of deals use cash as payment; and most of the target firms are unlisted firms. We also use the Stock price run-up variable, defined as acquirer's buy and hold return relative to the buy and hold return of CRSP value-weighted index during the period (-210, -11), to capture the possible mispricing of equity prior to the M\&A (Hansen, 1987; Myers and Majluf, 1984; Shleifer and Vishny, 2003).

Panel B of Table 2 reports correlations between key variables in the CBA acquirer sample. Bank ownership is positively related to CBA activity as measured by deal value, while family ownership is negatively related. The correlation between cross border M\&A activity and mutual fund ownership is negative and marginally significant. Also note that at the bivariate level, CAR is not significantly correlated with any blockholder ownership variables.

\section{Results}

We first examine how blockholder ownership influences a firm's acquisitiveness, starting with a univariate comparison of key variables between cross border acquirers and firms with no cross-border activities, followed by a Probit model examining the association between blockholdings and the likelihood of CBAs. We then study the relation between the CBA transaction value and voting rights held by different blockholders. Next we explore the change of block ownership from before to after the announcement of CBAs, testing blockholders' voting with feet following a major firm investment decision in the context of PP conflicts. Lastly, we investigate whether block ownership and the balance of power among competing blockholders affect the overall shareholder wealth of CBAs.

\subsection{Blockholding and acquisitiveness}

${ }^{8}$ Unless otherwise specified, we define industry following these categories throughout the method. 
Table 3 reports univariate comparisons of means and medians of blockholder ownership and firm characteristics for the CBA and non-CBA samples. Non-CBAs include all firms with available ownership and firm variables that do not have any CBAs over our sample period of 2002-2016, excluding finance and utility firms. ${ }^{9}$ The results show that CBAs have significantly higher bank ownership, lower mutual fund ownership, and much lower family ownership than non-CBAs. On average, the bank, mutual fund, and family blockholding in CBAs are $16 \%$ higher, $2 \%$ lower and $10 \%$ lower than those in non-CBAs, respectively. CBA firms also have a more unbalanced ownership structure between blockholders than non-CBAs. The difference between the bank and family ownership in CBAs is $25.4 \%$ (27.6\%) on average (median); and the mutual fund ownership is $10.4 \%$ (9.9\%) higher than family ownership on average (median) in CBAs. Both differences are much higher than those in non-CBAs, which are $-0.7 \%(0 \%)$ and $2.6 \%$ (0\%), respectively. Moreover, CBAs are larger than non-CBAs with lower market-to-book ratio, lower leverage and lower cash ratio. Finally, CBAs have much higher international business intensity measured by the proportion of total firm sales coming from foreign operations.

Insert Table 3 about here

We now turn to formally testing how blockholding structure affects the likelihood of CBAs in a multivariate framework. Table 4 reports estimations from Probit models of a firm's likelihood of doing a CBA on the three groups of blockholder ownership. The dependent variable is a dummy variable equal to one for cross-border acquirers, and zero for non-CBAs. Following Lee et al. (2017) and Gugler et al. (2012), we include firm size, market-to-book, leverage and

\footnotetext{
${ }^{9}$ Non-CBAs include both firms without any M\&As and firms with domestic M\&As but no cross border acquisitions. Results are robust if we only compare cross border acquirers and firms without any M\&As.
} 
cash ratio as controls. We also include the foreign-to-total sales ratio as an additional control variable, expecting that firms with more foreign sales and thus prior international experiences are more likely to undertake CBAs (Reus and Lamont, 2009). All regressions control for industry and year fixed effects, and standard errors (in parentheses) are corrected for heterogeneity and clustering at the industry level. To evaluate economic significance, we report the marginal effects on the probability of CBA for a one standard deviation change of the ownership variables in square brackets underneath the standard errors, holding other variables at their mean levels.

Insert Table 4 about here

The results show that different blockholding types have different effects on the likelihood of CBA. In particular, the impact of bank blockholding is significantly positive, with a one standard deviation increase in bank ownership increasing the CBA likelihood by 5\% (column (1)) or $4 \%$ (column (4)). The positive relation reflects a lower conflict between banks and management, lending evidence to a silent bank to management-driven CBAs or collaboration between banks and management in undertaking CBAs, or both. In contrast, the coefficient of mutual fund blockholding is statistically insignificant and economically trivial. Mutual funds, as return-oriented investors, would support value increasing CBAs and oppose value-decreasing CBAs. They may choose to express their opinion either by voice or by selling shares and withdrawing their investment in the firm. As we see, the net effect is an insignificant relation between mutual fund ownership and CBA likelihood. Lastly, family blockholding is significantly negatively related to the likelihood of a CBA. A one standard deviation increase in family ownership decreases the likelihood of a CBA by $4 \%$ (column (3)) or $2 \%$ (column (4)). This is 
consistent with the existing literature that suggests that family firms are more conservative and thereby reluctant to expand across borders. Overall, these results support $\mathrm{H} 1$ on the relations between blockholdings and firm's propensity to undertake CBAs, reflecting heterogeneous preferences of different blockholders in firm's international investment decisions.

Conditioning on a firm having made the decision to undertake a CBA, we further examine the relation between blockholding and the size of deals. Since the decision to engage in a CBA is made at the individual firm level, CBA acquirers constitute a self-selected sample and not a random sample. If the selection (or decision-making) process is not independent of the outcomes of the CBAs, it may lead to biased inferences regarding the outcomes. To address this potential selection problem, for all tests on CBA outcomes here and after, we use a Heckman two-stage estimation procedure. In the first stage, we estimate a Probit model of the decision to undertake a CBA, as in Table 4. In the second stage deal outcome regressions, we include as an additional explanatory variable the inverse Mills ratio (IMR) from the Probit model. The inclusion of IMR in the second stage regression mitigates potential selection bias and eliminates it asymptotically. Table 5 reports the regressions of the logarithm of deal value on ownership variables, controlling for firm characteristics, selection bias, industry and year fixed effects.

Insert Table 5 about here

The results show statistically significant evidence that family blockholding is negatively related to transaction value, supporting H1a. However, neither banking nor mutual fund blockholding is significantly related to transaction value. This may not be surprising. Note that mutual funds objective is financial returns which are not necessarily positively related to deal 
size. While we expect clientele relationship with banks may provide support to undertake large deals, in practice banks may support CBAs regardless of deal size.

\subsection{Blockholder ownership change after acquisition decision}

Shareholders preserve the right to vote with their feet, choosing to reduce and/or eliminate ownership after major events. Cross-border expansion is a major corporate investment decision, so a study of the post CBA blockholding change is suggestive of the PP conflicts. Using family ownership as the benchmark, we focus on the blockholding changes by banks and mutual funds. Following Parrino et al. (2003), we calculate both the change of the ownership and the change of the total number of blockholders, measured from the year immediately before the CBA announcement to the year after the announcement. We examine whether the ex post change is related to the presence of high ownership of other blockholders prior to the deal announcement, especially family blockhoders. The results are reported in Table 6.

\section{Insert Table 6 about here}

Bank and mutual fund blockholding changes are the dependent variables in columns (1) and (3) of Table 6, respectively, and the changes of the number of the bank and mutual fund block holders are the dependent variables in columns (2) and (4). The independent variables are ownerships of family, banks and mutual funds before the announcement date. All regressions control for deal and firm characteristics, as well as industry, year, and country fixed effects. We include target country dummies to control for the influences of cultural, economic, and political differences of target firm countries. 
We argue that banks are relatively inactive, with less conflict with family holders. Therefore, banks are less likely to exit due to high family ownership. On the other hand, mutual funds are more active and more likely to vote with their feet when there is high family ownership. We find no evidence that banks exit after a CBA with respect to family blockholding. In sharp contrast, however, mutual funds significantly reduce or eliminate their ownership in response to CBA when family blockholding is higher. These findings are consistent with $\mathrm{H} 2$. The latter result is robust to using both the change in shares and the change in number of blocks. This suggests that mutual fund interests may not coincide with the interests of family owners in CBAs. As such, higher family influence on major decisions may predict an exit of mutual funds.

\subsection{Shareholder wealth effects and blockholdings}

The last question we examine is how blockholdings and PP conflicts affect shareholder wealth at the announcement of a CBA. We calculate three-day CARs around the CBA announcement. To explore the effect of PP conflicts on shareholder value, we calculate the difference in blockholdings between bank and family and between mutual fund and family. We stratify the sample into three groups based on some critical cutoffs of the ownership difference between blockholders: ownership difference less than $-5 \%$, between $-5 \%$ and $5 \%$, and greater than $5 \%$. We use $5 \%$ as the cutoff point as it is often used to suggest sufficient block of interests in a firm, that is, a blockholder should have at least 5\% more voting rights than another blockholder to be sufficiently more interested in a firm (Holderness, 2009). Figure 1 plots the mean CARs of each group ( $\mathrm{Y}$ axis) against the mean ownership differences of each group (X axis). The solid line represents the relation between CARs and the ownership difference between mutual fund and family blockholding; and the dotted line represents the relation between CARs 
and the ownership difference between bank and family blockholdings. The solid line is much steeper than the dotted line, suggesting a possible larger conflict between mutual fund and family owners. Overall, the graph shows that CAR is the highest when the ownership difference is within negative and positive $5 \%$, consistent with our $\mathrm{H} 3$ that the balance of power tends to benefit shareholders.

Insert Figure 1 about here

To explore this relation in a multivariate setting, we define dummy variable $D$ Low $_{\text {Bank- }}$ Family equal to 1 if the blockholding difference between bank and family is less than $-5 \%$; and define dummy variable $D H i g h_{\text {Bank-Family }}$ equal to 1 if the blockholding difference between bank and family is higher than 5\%. DLow $w_{M F-F a m i l y}$ and DHigh $h_{M-F a m i l y}$ are similarly defined. We estimate CAR regressions using these ownership difference dummies as independent variables. The left-out group is deals with blockholding difference between $-5 \%$ and $5 \%$, where there is a more equally distributed power between blockholders. The results are reported in Table 7.

\section{Insert Table 7 about here}

When there is no extreme ownership dominance, we expect a higher CBA performance (H3), because of stronger monitoring effects by both conflicting blockholders. Supporting this hypothesis, our results show that the coefficients of both $D L O w_{M F-F a m i l y}$ and DHigh $h_{M F-F a m i l y}$ are significantly negative, indicating a higher shareholder wealth when blockholding difference between mutual funds and families is within $-5 \%$ to $5 \%$. As expected, results also show that the 
relative balance of power between banking and family blockholders has no effect on CARs. ${ }^{10}$

\section{Robustness}

We conduct a series of additional tests to check the robustness of our results. Our results are robust to using direct ownership of blockholders instead of relative ownership variables. Our results hold when we replace the country fixed effect with country specific variables that measure the disparities between target country and US in cultural, financial environment, economic environment, demographics, and technology. For space limit, the results are omitted here but available upon request.

In cases when family blockholders are also in the top management of the focal firm, we expect the influence of family blockholding would be even stronger. To examine this effect, we identify firms with a family member as CEO and define a variable CEO family ownership as the proportion of relative voting shares owned by families when one family member is the firm's CEO. We rerun all our tests using CEO family ownership as independent variable. As expected, we find a significant negative relation between the likelihood of a CBA and CEO family ownership, with a bigger magnitude than the relation between CBA propensity and family blockholding. When a decision to do CBA has been made, we find mutual funds tend to exit (as suggested by the change in number of mutual fund blockholders) with higher CEO family ownership, suggesting a severe conflict between mutual funds and powerful families. In general, these results suggest that the empirical evidence supporting our hypotheses is more salient in family-managed, family-owned acquirers. For space limit, the results are omitted here but

\footnotetext{
${ }^{10}$ We focus on the balance of power between conflicting blockholders - mutual funds versus family and banks versus family. As an additional check, we also test the effect of the power distribution between two financial institution blockholders - mutual funds versus banks. We do not expect to find significant effect and the results (available upon request) are consistent.
} 
available upon request.

Finally, we examine how the 2007-09 financial crisis affects the documented relations. To do so, we create three dummy variables according to the recession period defined by National Bureau of Economic Research (NBER): Pre-crisis dummy equal to one if a deal is announced before December 2007, Crisis dummy equal to one if a deal is announced between December 2007 to June 2009, and Post-crisis dummy equal to one if a deal is announced after June 2009. We interacted the first two dummies with dependent variables to test for the moderating effects of financial crisis. Overall, we find consistent results across all periods, with the exception of H3 related to banks. After the crisis, the balanced power between banks and the family leads to higher CARs, similarly to the findings related to mutual funds. This may reflect the fact that banks as shareholders become more financially disciplined and hence active in monitoring the management (and the controlling family) after the financial crisis. For space limit, the results are omitted but available upon request.

\section{Discussion and Conclusions}

The current literature on how blockholder PP conflicts and corresponding governance mechanisms affect MNE activities and performance is limited. In this study, we try to fill this gap by examining the heterogeneous preferences of three blockholder groups (families, banks, and mutual funds) in a firm's CBA and the mechanisms through which the three groups influence and confluence the CBA behaviors and outcomes. A distinct shareholder type is family blockholder, whose interests are often dominated by non-pecuniary benefits known as socioeconomic wealth. These concerns make them more risk-averse and more reluctant to engage in a risky undertaking such as CBAs. Beyond family blockholders, we distinguish 
between pressure-sensitive (e.g., banks) and pressure-resistant blockholders (e.g., mutual funds) based on their vital business relations with firms. Banks tend to build and maintain client relationship with firms and the collaboration between bank blockholders and management helps promote firms pursuing more CBAs, regardless of the deal size. Compared to banks, mutual funds are more return-oriented and more selective in potential CBA projects. Our findings indicate that PP conflicts in CBA are mainly between family and mutual fund blockholders. We provide evidence showing that mutual funds will choose to exit after CBA when faced with high family power. Further, we show that balance of power between the families and mutual funds may induce effective monitoring and discipline, leading to higher overall shareholder value in CBAs. In contrast, banks act more passively as equity holders and are not found to have the same PP conflict effects, likely because of their pressure sensitivity to the management. Overall, our findings suggest that examining the multiple blockholder structure helps to better understand MNE's strategic behaviors and performance.

Our study opens a few avenues for future research. First, we show how the PP conflicts and particularly the balance of power among blockholders influence a firm's CBA decisions and shareholder wealth. This can be further expanded to study how PP conflicts influence other corporate decisions, corporate governance and firm value. There is also an important gap to fill in theoretical modeling of the effects of PP conflicts. New models should take into account diversified shareholder objective functions, which not only include economic self-interests but also nonmarket, social objectives. Recent studies have started to question the foundational assumption that shareholders are (supposed to be) homogeneous, economically-oriented, and narrowly self-interested. For instance, Hart and Zingales (2016) suggest that the ultimate shareholders (principals) as human beings are not only concerned about monetary benefits, but 
are also prosocial and may, to some extent, internalize their public concerns into shareholder pressures. This is especially important in companies with multiple powerful shareholders pursuing different private benefits of control.

Second, future studies may explore more the PP conflicts in an international context, where the institutional structure is often more complicated. In the context of US, with a developed and transparent financial market, our study equates formal voting rights with blockholder power, and focuses on shareholder monitoring with voice and voting with feet as ways in which blockholders exert their influence over the manager. This focus on formal mechanisms assumes away the possibilities that powerful shareholders may also informally pressure the manager in ways that are unrelated to their formal votes (Ahmadjian and Robbins, 2005; Davis and Thompson, 1994; Fligstein and Brantley, 1992; Kang and Sørensen, 1999), such as social capital, influence in social or public media, and political and diplomatic advantages. The informal influence might be prevalent in countries where financial markets are less developed (for example, lack of a liquid market for voting with feet) limiting the functions of formal mechanisms. Expanding our study to a cross-national setting and incorporating the variations in informal shareholder pressures into the power distribution between contesting blockholders will cast more light on the PP conflicts and corporate governance.

Third, we have implicitly assumed that management decisions and board of directors impartially and proportionally represent the power of shareholders, which may not always be true in many countries. Due to data limitation, we do not have information on the distribution of board seats owned by blockholders. Future studies may focus more closely on the relation between the owners' voting power and board/management representations. Some shareholders may be disproportionally more represented than others in the boardroom and the C-suite (i.e., top 
senior executives), not only as a result of their formal influence but also due to shared interests and preferences with the management. Since the agent's preferences affect how they see their fiduciary duties (Aguilera and Jackson, 2003; Bosse and Phillips, 2016), it is likely the effects of blockholder PP conflicts are a mixed consequence of not only the PP power contest but also the varying preferences and beliefs of the agent. 


\section{Reference}

Aguilera, R.V., Jackson, G., 2003. The cross-national diversity of corporate governance: Dimensions and determinants. Academy of Management Review 28, 447-465.

Ahmadjian, C.L., Robbins, G.E., 2005. A clash of capitalisms: Foreign shareholders and corporate restructuring in 1990s Japan. American Sociological Review 70, 451-471.

Anderson, R.C., Duru, A., Reeb, D.M., 2012. Investment policy in family controlled firms. Journal of Banking and Finance 36, 1744-1758.

Anderson, R.C., Reeb, D.M., 2003. Founding- family ownership and firm performance: evidence from the S\&P 500. Journal of Finance 58, 1301-1328.

André, P., Ben-Amar, W., Saadi, S., 2014. Family firms and high technology Mergers \& Acquisitions. Journal of Management \& Governance 18, 129-158.

Arregle, J., Duran, P., Hitt, M.A., van Essen, M., 2017, Why is family firms' internationalization unique? A meta-analysis. Entrepreneurship Theory and Practice 41, 661-875.

Attig, N., El Ghoul, S., Guedhami, O., 2009, Do multiple large shareholders play a corporate governance role? Evidence from East Asia. Journal of Financial Research 32, 395-422.

Banalieva, E.R., Eddleston, K.A., 2011. Home-region focus and performance of family firms: The role of family vs non-family leaders. Journal of International Business Studies 42, 1060-1072.

Becht, M., Polo, A., Rossi, S., 2016. Does mandatory shareholder voting prevent bad acquisitions? Review of Financial Studies 29, 3035-3067.

Berrone, P., Cruz, C., Gómez-Mejía, L.R., 2012. Socioemotional wealth in family firms theoretical dimensions, assessment approaches, and agenda for future research. Family Business Review 25, 258-279.

Berrone, P., Cruz, C., Gómez-Mejía, L.R., Larraza-Kintana, M., 2010. Socioemotional wealth and corporate responses to institutional pressures: Do family-controlled firms pollute less? Administrative Science Quarterly 55, 82-113.

Bharath, S.T., Jayaraman, S., Nagar, V., 2013. Exit as governance: An empirical analysis. Journal of Finance 68, 2515-2547.

Black, B., Coffee, J., 1994. Hail Britannia? Institutional investor behavior under limited regulation. Michigan Law Review 92, 1997-2087.

Boellis, A., Mariotti, S., Minichilli, A., Piscitello, L., 2016. Family involvement and firms' establishment mode choice in foreign markets. Journal of International Business Studies 47, 929-950.

Bosse, D.A., Phillips, R.A., 2016. Agency theory and bounded self-interest. Academy of Management Review 41, 276-297.

Brickley, J.A., Lease, R.C., Smith, C.W., 1988. Ownership structure and voting on antitakeover amendments. Journal of Financial Economics 20, 267-291.

Brossard, O., Lavigne, S., Sakinc, M.E., 2013. Ownership structures and R\&D in Europe: the good institutional investors, the bad and ugly impatient shareholders. Industrial and Corporate Change 22, 1013-1068.

Caprio, L., Croci, E., Del Giudice, A., 2011. Ownership structure, family control, and acquisition decisions. Journal of Corporate Finance 17, 1636-1657.

Chen Y.Y., Young M.N., 2010. Cross-border mergers and acquisitions by Chinese listed companies: A principalprincipal perspective. Asia Pacific Journal of Management 27, 523-539.

Chowdhury, S.D., Wang, E.Z., 2009. Institutional activism types and CEO compensation: A time-series analysis of large Canadian corporations. Journal of Management, 35, 5-36.

Chung, K., Kim, J., 1999. Corporate ownership and the value of a vote in an emerging market. Journal of Corporate Finance 5, 35-54. 
Crespi, R., Renneboog, L., 2010. Is (institutional) shareholder activism new? Evidence from UK shareholder coalitions in the pre-cadbury Era. Corporate Governance: An International Review 18, 274-295.

Daily, C.M., Dalton, D.R., Rajagopalan, N., 2003. Governance through ownership: Centuries of practice, decades of research. Academy of Management Journal 46, 151-158.

Dalton, D.R., Daily, C.M., Certo, S.T., Roengpitya, R., 2003. Meta-analyses of financial performance and equity: fusion or confusion? Academy of Management Journal 46, 13-26.

Davis, G.F., Thompson, T.A., 1994. A social movement perspective on corporate control. Administrative Science Quarterly 39, 141-173.

David, P., Kochhar, R., Levitas, E., 1998. The effect of institutional investors on the level and mix of CEO compensation. Academy of Management Journal 41, 200-208.

David, P., Kochhar, R., 1996. Barriers to effective corporate governance by institutional investors: Implications for theory and practice. European Management Journal 14, 457-466.

Dikova, D., Sahib, P.R., 2013. Is cultural distance a bane or a boon for cross-border acquisition performance? Journal of World Business 48, 77-86.

D’Mello, I., Demiralp, R., Schlingemann, F.P., Subramaniam, V., 2011. Are there monitoring benefits to institutional ownership? Evidence from seasoned equity offerings. Journal of Corporate Finance 17, 1340-1359.

Duan, Y., Jiao, Y., 2016. The role of mutual funds in corporate governance: evidence from mutual funds' proxy voting and trading behavior. Journal of Financial and Quantitative Analysis 51, 489-513.

Eaton, J., Gersovitz, M., Stiglitz, J.E., 1986. The pure theory of country risk. European Economic Review 30, 481-513.

Edmans, A., 2014. Blockholders and corporate governance. Annual Review of Financial Economics 6, 23-50.

Edmans, A., Manso, G., 2011. Governance through trading and intervention: A theory of multiple blockholders. Review of Financial Studies 24, 2395-2428.

Fama, E.F., Jensen, M.C., 1983. Separation of ownership and control. Journal of Law \& Economics 26, 301-325.

Ferreira M.A., Massa, M., Matos, P., 2010, Shareholders at the gate? institutional investors and cross-border mergers and acquisitions. Review of Financial Studies 23, 601-644.

Filatotchev, I., Wright, M., 2011. Agency perspectives on corporate governance of multinational enterprises. Journal of Management Studies 48, 471-486.

Fligstein, N., Brantley, P., 1992. Bank control, owner control, or organizational dynamics: Who controls the large modern corporation?. American Journal of Sociology 98, 280-307.

Francis, B.B., Hasan, I., Sun, X., 2008. Financial market integration and the value of global diversification: Evidence for US acquirers in cross-border mergers and acquisitions. Journal of Banking and Finance 32, 1522-1540.

Gomez-Mejia, L.R., Patel, P.C., Zellweger, T.M., 2015. In the horns of the dilemma socioemotional wealth, financial wealth, and acquisitions in family firms. Journal of Management 17, 0149206315614375.

Gomez- Mejia, L.R., Makri, M., Kintana, M.L., 2010. Diversification decisions in family- controlled firms. Journal of Management Studies 47, 223-252.

Goranova, M., Zajac, E., 2015. Principal Costs: Reversing the polarity of the principal-agent dyad. Academy of Management Proceedings.

Greenberg, D.N., Lane, H.W., Bahde, K., 2005. Organizational learning in cross-border mergers and acquisitions. Mergers and acquisitions: Managing culture and human resources, 53-76.

Gugler, K., Mueller, D.C., Weichselbaumer, M., 2012. The determinants of merger waves: An international perspective. International Journal of Industrial Organization 30, 1-15.

Habbershon, T.G., Williams, M.L., 1999. A resource-based framework for assessing the strategic advantages of 
family firms. Family Business Review 12, 1-25.

Haleblian, J., Devers, C.E., McNamara, G., Carpenter, M.A., Davison, R.B., 2009. Taking stock of what we know about mergers and acquisitions: A review and research agenda. Journal of Management 35, 469-502.

Hansen, R.G., 1987. A theory for the choice of exchange medium in mergers and acquisitions. Journal of Business 60, 75-95.

Hart, O., Zingales, L. 2016. Should a company pursue shareholder value? Working paper.

Hayward, M.L., Hambrick, D.C, 1997. Explaining the premiums paid for large acquisitions: Evidence of CEO hubris. Administrative Science Quarterly 42, 103-127.

Helwege, J., Intintoli, V.J., Zhang, A., 2012. Voting with their feet or activism? Institutional investors' impact on CEO turnover. Journal of Corporate Finance 18, 22-37.

Holderness, C., 2009. The myth of diffuse ownership in the United States. Review of Financial Studies 22, 1377-1408.

Iliev, P., Lowry, M., 2015. Are mutual funds active voters? Review of Financial Studies 28, 446-485.

Jensen, M.C., Meckling, W.H., 1976. Theory of the firm: Managerial behavior, agency costs and ownership structure. Journal of Financial Economics 3, 305-360.

John, K., Knyazeva, A., Knyazeva, D., 2015. Employee rights and acquisitions. Journal of Financial Economics 118, 49-69.

Kang, D.L., Sørensen, A.B., 1999. Ownership organization and firm performance. Annual Review of Sociology 25, 121-144.

Kontinen, T., Ojala, A., 2010. The internationalization of family businesses: A review of extant research. Journal of Family Business Strategy 1, 97-107.

Lee, K.H., Mauer, D.C., Xu, E., 2017. Human capital relatedness and mergers and acqusitions. Journal of Financial Economics, Forthcoming.

Lien, Y-C., Filatotchev, I., 2015. Ownership characteristics as determinants of FDI location decisions in emerging economies. Journal of World Business 50, 637-650.

Mantecon, T., 2009. Mitigating risks in cross-border acquisitions. Journal of Banking and Finance 33, 640-651.

Maury, B., Pajuste, A., 2005. Multiple large shareholders and firm value. Journal of Banking and Finance 29, 1813-1834.

Miller, D., Breton- Miller, L., Lester, R.H., 2010. Family ownership and acquisition behavior in publicly- traded companies. Strategic Management Journal 31, 201-223.

Moeller, S.B., Schlingemann, F.P., 2005. Global diversification and bidder gains: A comparison between cross-border and domestic acquisitions. Journal of Banking and Finance 29, 533-564.

Moeller, S.B., Schlingemann, F.P., Stulz, R.M., 2005. Wealth destruction on a massive scale? A study of acquiringfirm returns in the recent merger wave. Journal of Finance 60, 757-782.

Morck, R., Wolfenzon, D., Yeung, B., 2005. Corporate governance, economic entrenchment, and growth. Journal of Economic Literature 43, 655-720.

Morgan, A., Poulsen, A., Wolf, J., Yang, T., 2011. Mutual funds as monitors: Evidence from mutual fund voting. Journal of Corporate Finance 17, 914-928.

Myers, S.C., Majluf, N.S., 1984, Corporate financing and investment decisions when firms have information that investors do not have. Journal of Financial Economics 13, 187-221.

Parrino, R., Sias, R.W., Starks, L.T., 2003. Voting with their feet: Institutional ownership changes around forced CEO turnover. Journal of Financial Economics 68, 3-46.

Pukall, T.J., Calabrò, A., 2014. The internationalization of family firms: A critical review and integrative model. Family Business Review 27, 103-125. 
Reus, T.H., Lamont, B.T., 2009. The double-edged sword of cultural distance in international acquisitions. Journal of International Business Studies 40, 1298-1316.

Seth, A., Song, K.P., Pettit, R., 2000. Synergy, managerialism or hubris? An empirical examination of motives for foreign acquisitions of US firms. Journal of International Business Studies 31, 387-405.

Seth, A., Song, K.P., Pettit, R.R., 2002. Value creation and destruction in cross- border acquisitions: an empirical analysis of foreign acquisitions of US firms. Strategic Management Journal 23, 921-940.

Sherman, H., Beldona, S., Joshi, M., 1998. Institutional investor heterogeneity: Implications for strategic decisions. Corporate Governance: An International Review 6, 166-173.

Shleifer, A., Vishny, R.W., 1997. A survey of corporate governance. Journal of Finance 52, 737-783.

Shleifer, A., Vishny, R.W., 2003. Stock market driven acquisitions. Journal of Financial Economics 70, 295-311.

Sluhan, A. 2016. Familiness, socioemotional wealth, and internationalization of family firms: A review of capabilities and motivations in different modes of internationalization. In: Kellermanns, F, Hoy, F (Eds), The Routledge Companion to Family Business. New York, NY: Routledge.

Thomsen, S., Pedersen, T., 2000. Ownership structure and economic performance in the largest European companies. Strategic Management Journal 21, 689-705.

Tihanyi, L., Johnson, R.A., Hoskisson, R.E., Hitt, M.A., 2003. Institutional ownership differences and international diversification: The effects of boards of directors and technological opportunity. Academy of Management Journal, 46, 195-211.

Van Essen, M., Otten, J., Carberry, E.J., 2015. Assessing managerial power theory: A meta-analytic approach to understanding the determinants of CEO compensation. Journal of Management 41, 164-202.

Ward, J.L. 2004. Perpetuating the family business: 50 lessons learned from long lasting, successful families in business. Basingstoke, UK: Palgrave Macmillan.

Wright, P., Ferris, S.P., Sarin, A., Awasthi, V., 1996. Impact of corporate insider, blockholder, and institutional equity ownership on firm risk taking. Academy of Management Journal 39, 441-458.

Zahra, S.A., Neubaum, D.O., Huse, M., 2000, Entrepreneurship in medium-size companies: Exploring the effects of ownership and governance systems. Journal of Management 26, 947-976. 


\section{Appendix: Variable definition}

\section{Variable}

\section{Dependent variables}

Log CBMA value

$\Delta$ Bank ownership

$\Delta$ No. Bank blockholders

$\Delta$ Mutual fund ownership

$\Delta$ No. mutual fund

CARs $[-1,+1]$

\section{Ownership Variables}

Bank ownership

Mutual fund ownership

Family ownership

CEO family ownership

Ownership diff Bank - family $_{\text {. }}$

Ownership $\operatorname{diff}{ }_{\mathrm{MF}-\text { family }}$

DLow $_{\text {Bank - Family }}$

DHigh $_{\text {Bank - Family }}$

DLow $_{\text {MF- Family }}$

DHigh $_{\mathrm{MF}-\text { Family }}$

\section{Definition (Source of data)}

Logarithm of the deal values of cross-border M\&As by a firm in one fiscal year. Deal values are in millions of 2015 constant dollars. (Zephyr)

The change of bank ownership from $t$ to $t+1$, where $t$ is the year immediately before merger announcement. (Orbis)

The change of the number of bank blockhoders from $t$ to $t+1$, where $t$ is the year immediately before merger announcement. (Orbis)

The change of mutual fund ownership from $t$ to $t+1$, where $t$ is the year immediately before the merger announcement. (Orbis)

The change of the number of mutual fund blockhoders from $t$ to $t+1$, where $t$ is the year immediately before merger announcement. (Orbis)

Three-day cumulative abnormal returns of acquirer calculated using market model. The market model parameters are estimated over the period $(-210,-11)$ with the CRSP value-weighted return as the market index. (CRSP)

Proportion of relative voting shares owned by banks. (Orbis)

Proportion of relative voting shares owned by mutual fund. (Orbis)

Proportion of relative voting shares owned by one or more named individuals or families. (Orbis)

Proportion of voting shares owned by families when one family member is the firm CEO. (Orbis)

The difference of ownership between banks and family (Bank ownership minus Family ownership). (Orbis)

The difference of ownership between mutual fund and family (MF ownership minus Family ownership). (Orbis)

Dummy variable equals one if Ownership diff $f_{\text {Bank-family }}$ is less than $-5 \%$, and zero otherwise. (Orbis)

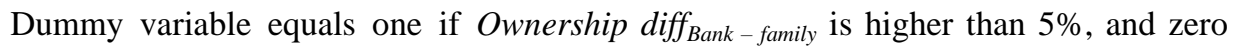
otherwise. (Orbis)

Dummy variable equals one if Ownership diff $f_{M F-f a m i l y}$ is less than -5\%, and zero otherwise. (Orbis)

Dummy variable equals one if Ownership diff ${ }_{M F-\text { family }}$ is higher than $5 \%$, and zero otherwise. (Orbis)

\section{Firm characteristic variables}

Log (total assets)

Logarithm of market value of assets in constant dollars, where market value of assets is Log (total assets) Logarithm of the book value of total assets in constant dollars. (Compustat) 
Market to book

Market leverage

Cash ratio

Foreign sales / Sales

\section{Deal characteristics}

Diversifying deal dummy

Cash pay dummy

Stock pay dummy

Unlisted dummy

Stock price run-up
Ratio of book value of assets plus the difference between the market and book values of equity to book assets. (Compustat)

The ratio of book value of debt (debt in current liabilities + long-term debt) to market value of total assets. (Compustat)

Ratio of cash and marketable securities to book value of assets. (Compustat)

Volume of foreign sales to total firm sales. (Segement/Compustat)

Dummy variable equal to one if acquirer and target do not share the same Fama-French 49 industry categories, and zero otherwise. (Zephyr)

Dummy variable equal to one if the deal payment is financed by cash, and zero otherwise. (Zephyr)

Dummy variable equal to if the deal payment financed by stock, and zero otherwise. (Zephyr)

Dummy variable equal to one if the target's status is unlisted, and zero otherwise. (Zephyr)

Acquirer's buy-and-hold return relative to the buy and hold return of market index during the period $(-210,-11)$. The market index is the CRSP value-weighted portfolio. (CRSP) 
Table 1. Sample distribution

The sample includes complete cross-border mergers and acquisitions from Zephyr by US public firms announced over 2003 to 2016. We require acquirers to have block ownership information from Orbitz, major firm data from Compustat, and stock return data from CRSP. We also require non-missing target country information, and at least 10 deals in each target country over the sample period. Deals in tax heavens, and deals where either acquirer or target are finance firms (SIC code between 6000 to 6999) or regulated utilities (SIC code between 4900 to 4999 ) are excluded. Panel A reports sample distribution by year. Panel B reports sample distribution by target firms' country.

\begin{tabular}{lcr}
\hline \multicolumn{3}{l}{ Panel A. Sample distribution by year } \\
\hline $\begin{array}{l}\text { Year of deal } \\
\text { announcement }\end{array}$ & No. of deals & $\%$ \\
\hline 2003 & 33 & 1.20 \\
2004 & 103 & 3.74 \\
2005 & 77 & 2.80 \\
2006 & 74 & 2.69 \\
2007 & 173 & 6.29 \\
2008 & 254 & 9.23 \\
2009 & 146 & 5.31 \\
2010 & 251 & 9.12 \\
2011 & 292 & 10.61 \\
2012 & 272 & 9.88 \\
2013 & 281 & 10.21 \\
2014 & 327 & 11.88 \\
2015 & 288 & 10.47 \\
2016 & 181 & 6.58 \\
\hline Total & 2,752 & 100.00 \\
\hline
\end{tabular}

Panel B. Sample distribution by target country

\begin{tabular}{|c|c|c|}
\hline Target country & No. of deals & $\%$ \\
\hline Australia & 141 & 5.12 \\
\hline Austria & 19 & 0.69 \\
\hline Belgium & 36 & 1.31 \\
\hline Brazil & 120 & 4.36 \\
\hline Canada & 395 & 14.35 \\
\hline Chile & 14 & 0.51 \\
\hline China & 100 & 3.63 \\
\hline Czech Republic & 15 & 0.55 \\
\hline Denmark & 45 & 1.64 \\
\hline Finland & 26 & 0.94 \\
\hline France & 155 & 5.63 \\
\hline Germany & 236 & 8.58 \\
\hline Hong Kong & 16 & 0.58 \\
\hline India & 85 & 3.09 \\
\hline Ireland & 59 & 2.14 \\
\hline Israel & 93 & 3.38 \\
\hline Italy & 90 & 3.27 \\
\hline Japan & 20 & 0.73 \\
\hline Mexico & 44 & 1.60 \\
\hline Netherlands & 122 & 4.43 \\
\hline New Zealand & 24 & 0.87 \\
\hline Norway & 33 & 1.20 \\
\hline Poland & 18 & 0.65 \\
\hline Portugal & 10 & 0.36 \\
\hline Republic of Korea & 24 & 0.87 \\
\hline Russian Federation & 14 & 0.51 \\
\hline Singapore & 25 & 0.91 \\
\hline South Africa & 20 & 0.73 \\
\hline Spain & 46 & 1.67 \\
\hline Sweden & 74 & 2.69 \\
\hline Switzerland & 70 & 2.54 \\
\hline Turkey & 16 & 0.58 \\
\hline United Kingdom & 547 & 19.88 \\
\hline Total & 2,752 & 100.00 \\
\hline
\end{tabular}


Table 2. Summary statistics and correlation matrix

Panel A reports summary statistics of main variables of cross border mergers and acquisitions. Detailed definitions of variables are provided in Appendix. Panel B reports Pearson correlation coefficients. We use a, b, and c to denote significance at $1 \%, 5 \%$, and $10 \%$, respectively.

Panel A. Summary statistics

\begin{tabular}{|c|c|c|c|c|c|c|}
\hline Variable & $\mathrm{N}$ & Mean & Std Dev & Min & Median & Max \\
\hline \multicolumn{7}{|l|}{ Ownership variables: } \\
\hline Bank ownership & 2,752 & 0.335 & 0.280 & 0.000 & 0.300 & 1.000 \\
\hline Mutual fund ownership & 2,752 & 0.186 & 0.213 & 0.000 & 0.139 & 1.000 \\
\hline Family ownership & 2,752 & 0.081 & 0.194 & 0.000 & 0.000 & 1.000 \\
\hline Ownership diff $f_{\text {Bank-family }}$ & 2,752 & 0.254 & 0.390 & -1.000 & 0.276 & 1.000 \\
\hline Ownership diff $\mathrm{MF-family}$ & 2,752 & 0.104 & & -1.000 & 0.099 & 1.000 \\
\hline DLow $_{\text {Bank-Family }}$ & 2,752 & 0.137 & & & & \\
\hline DHigh $_{\text {Bank-Family }}$ & 2,752 & 0.698 & & & & \\
\hline DLow $_{\text {MF-Family }}$ & 2,752 & 0.139 & & & & \\
\hline DHigh $_{\text {MF-Family }}$ & 2,752 & 0.521 & & & & \\
\hline \multicolumn{7}{|l|}{ Dependent variables } \\
\hline Log deal value & 1,034 & 10.964 & 1.783 & 1.496 & 10.973 & 16.503 \\
\hline$\Delta$ Bank ownership & 2,544 & -0.0002 & 0.193 & -0.624 & 0.000 & 0.677 \\
\hline$\Delta$ Mutual fund ownership & 2,544 & 0.023 & 0.155 & -0.556 & 0.000 & 0.531 \\
\hline$\Delta$ No. bank blockholders & 2,544 & 0.049 & 0.874 & -4.000 & 0.000 & 5.000 \\
\hline$\Delta$ No. mutual fund blockholders & & 0.150 & 0.947 & -6.000 & 0.000 & 6.000 \\
\hline CARs $[-1,+1]$ & & 0.005 & 0.040 & -0.139 & 0.003 & 0.200 \\
\hline \multicolumn{7}{|l|}{ Firm characteristics: } \\
\hline Log (total assets) & 2,752 & 8.021 & 1.848 & 1.751 & 8.015 & 11.834 \\
\hline Market to book & 2,752 & 2.181 & 1.283 & 0.640 & 1.819 & 15.797 \\
\hline Market leverage & 2,752 & 0.117 & 0.111 & 0.000 & 0.092 & 0.679 \\
\hline Cash ratio & 2,752 & 0.175 & 0.166 & 0.0004 & 0.120 & 0.978 \\
\hline Foreign sales / Sales & 2,752 & 0.412 & 0.254 & 0.000 & 0.416 & 1.000 \\
\hline \multicolumn{7}{|l|}{ Deal characteristics: } \\
\hline Diversifying deal dummy & 2,752 & 0.534 & & & & \\
\hline Cash pay dummy & 2,752 & 0.243 & & & & \\
\hline Stock pay dummy & 2,752 & 0.024 & & & & \\
\hline Unlisted dummy & 2,752 & 0.962 & & & & \\
\hline Stock price run-up & 2,696 & 0.032 & 0.226 & -0.509 & 0.0117 & 1.031 \\
\hline
\end{tabular}


Table 2 -Continued

\begin{tabular}{|c|c|c|c|c|c|c|c|c|c|c|c|}
\hline \multicolumn{12}{|l|}{ Panel B. Correlations } \\
\hline & 1 & 2 & 3 & 4 & 5 & 6 & 7 & 8 & 9 & 10 & 11 \\
\hline 1 Log CBMA Value & 1.000 & & & & & & & & & & \\
\hline $2 \Delta$ Bank ownership & -0.036 & 1.000 & & & & & & & & & \\
\hline $3 \Delta$ Mutual fund ownership & -0.017 & $-0.213^{\mathrm{a}}$ & 1.000 & & & & & & & & \\
\hline $4 \Delta$ No. bank blockholders & -0.020 & $0.384^{\mathrm{a}}$ & $-0.188^{\mathrm{a}}$ & 1.000 & & & & & & & \\
\hline $5 \Delta$ No. mutual fund blockholders & -0.003 & $-0.249^{\mathrm{a}}$ & $0.603^{\mathrm{a}}$ & $0.089^{\mathrm{a}}$ & 1.000 & & & & & & \\
\hline 6 CARs $[-1,+1]$ & $0.068^{\mathrm{b}}$ & 0.007 & -0.009 & 0.033 & -0.004 & 1.000 & & & & & \\
\hline 7 Bank ownership & $0.131^{\mathrm{a}}$ & $-0.453^{\mathrm{a}}$ & $0.091^{\mathrm{a}}$ & $-0.180^{\mathrm{a}}$ & $0.070^{\mathrm{a}}$ & 0.000 & 1.000 & & & & \\
\hline 8 Mutual fund ownership & $-0.057^{\mathrm{c}}$ & $0.054^{\mathrm{a}}$ & $-0.408^{\mathrm{a}}$ & $0.077^{\mathrm{a}}$ & $-0.220^{\mathrm{a}}$ & 0.015 & $-0.225^{\mathrm{a}}$ & 1.000 & & & \\
\hline 9 Family ownership & $-0.118^{\mathrm{a}}$ & $0.112^{\mathrm{a}}$ & 0.032 & $0.066^{\mathrm{a}}$ & 0.021 & -0.027 & $-0.324^{\mathrm{a}}$ & $-0.174^{\mathrm{a}}$ & 1.000 & & \\
\hline 10 Ownership diff ${ }_{\text {Bank-family }}$ & $0.154^{\mathrm{a}}$ & $-0.383^{\mathrm{a}}$ & $0.050^{\mathrm{a}}$ & $-0.157^{\mathrm{a}}$ & $0.038^{c}$ & 0.013 & $0.881^{\mathrm{a}}$ & $-0.076^{\mathrm{a}}$ & $-0.732^{\mathrm{a}}$ & 1.000 & \\
\hline 11 Ownership diff ${ }_{\mathrm{MF}-\text { family }}$ & 0.033 & $-0.033^{c}$ & $-0.298^{\mathrm{a}}$ & 0.010 & $-0.159^{\mathrm{a}}$ & 0.027 & $0.048^{\mathrm{b}}$ & $0.790^{\mathrm{a}}$ & $-0.741^{\mathrm{a}}$ & $0.404^{\mathrm{a}}$ & 1.000 \\
\hline Log (total assets) & $0.523^{\mathrm{a}}$ & -0.012 & $0.033^{\mathrm{c}}$ & -0.025 & -0.006 & $-0.096^{\mathrm{a}}$ & $0.230^{\mathrm{a}}$ & $-0.234^{\mathrm{a}}$ & $-0.075^{\mathrm{a}}$ & $0.203^{\mathrm{a}}$ & $-0.113^{\mathrm{a}}$ \\
\hline Market to book & -0.045 & -0.004 & 0.008 & $0.052^{\mathrm{a}}$ & 0.016 & 0.005 & $-0.090^{\mathrm{a}}$ & -0.025 & $0.130^{\mathrm{a}}$ & $-0.130^{\mathrm{a}}$ & $-0.098^{\mathrm{a}}$ \\
\hline Market leverage & $0.160^{\mathrm{a}}$ & 0.009 & 0.016 & -0.026 & 0.020 & $-0.041^{b}$ & -0.018 & 0.027 & $-0.085^{\mathrm{a}}$ & 0.029 & $0.071^{\mathrm{a}}$ \\
\hline Cash ratio & $0.137^{\mathrm{a}}$ & 0.014 & 0.000 & 0.013 & 0.009 & 0.019 & $-0.050^{\mathrm{a}}$ & -0.017 & $0.104^{\mathrm{a}}$ & $-0.088^{\mathrm{a}}$ & $-0.076^{\mathrm{a}}$ \\
\hline Diversifying deal dummy & $-0.064^{b}$ & $0.037^{\mathrm{c}}$ & -0.004 & $0.038^{\mathrm{c}}$ & -0.010 & 0.014 & $0.058^{\mathrm{a}}$ & $-0.048^{b}$ & $-0.052^{\mathrm{a}}$ & $0.068^{\mathrm{a}}$ & 0.000 \\
\hline Cash pay dummy & $0.091^{\mathrm{a}}$ & 0.025 & $-0.040^{\mathrm{b}}$ & $0.048^{\mathrm{b}}$ & 0.010 & $0.071^{\mathrm{a}}$ & -0.028 & $0.077^{\mathrm{a}}$ & $-0.047^{b}$ & 0.003 & $0.082^{\mathrm{a}}$ \\
\hline Stock pay dummy & $-0.068^{b}$ & 0.003 & -0.022 & 0.021 & -0.013 & $0.054^{\mathrm{a}}$ & $-0.098^{\mathrm{a}}$ & 0.025 & $0.053^{\mathrm{a}}$ & $-0.097^{\mathrm{a}}$ & -0.016 \\
\hline Unlisted dummy & $-0.232^{\mathrm{a}}$ & -0.024 & 0.011 & -0.008 & 0.005 & -0.035 & 0.001 & 0.002 & $0.048^{\mathrm{b}}$ & -0.023 & -0.028 \\
\hline Stock price run-up & 0.025 & -0.002 & 0.009 & 0.017 & -0.007 & $-0.039^{b}$ & -0.028 & -0.011 & -0.021 & -0.010 & 0.005 \\
\hline
\end{tabular}


Table 3. Comparison of ownership and firm variables between cross border acquirers (CBAs) and non-CBAs

The table compares the means and medians of ownership and firm variables between cross-border acquirers and firms with no cross-border activities during our sample period. All variables are defined in Appendix. The significance of the difference in means is based on a $t$-test that assumes unequal variances across groups when a test of equal variances is rejected at the 10 percent level. The significance of the difference in medians is based on a Wilcoxon rank-sum test. We use ${ }^{* *}, * *$, and $*$ to denote significance at the $1 \%, 5 \%$, and $10 \%$ levels respectively.

\begin{tabular}{|c|c|c|c|c|c|c|}
\hline \multirow[b]{2}{*}{ Variable } & \multicolumn{2}{|c|}{$\begin{array}{c}\text { Cross border } \\
\text { M\&A acquirers }\end{array}$} & \multicolumn{2}{|c|}{$\begin{array}{c}\text { Firms with no cross } \\
\text { border M\&A }\end{array}$} & \multicolumn{2}{|c|}{ Difference in } \\
\hline & Mean & Median & Mean & Median & Mean & Median \\
\hline \multicolumn{7}{|l|}{ Ownership variables: } \\
\hline Bank ownership & 0.335 & 0.300 & 0.175 & 0.000 & $0.160 * * *$ & $0.300 * * *$ \\
\hline Mutual fund ownership & 0.186 & 0.139 & 0.208 & 0.116 & $-0.022 * * *$ & 0.024 \\
\hline Family ownership & 0.081 & 0.000 & 0.182 & 0.000 & $-0.101 * * *$ & $0.000 * * *$ \\
\hline Ownership diff Bank-Bamily & 0.254 & 0.276 & -0.007 & 0.000 & $0.261^{* * *}$ & $0.276^{* * *}$ \\
\hline Ownership diff ${ }_{\text {MF-Bamily }}$ & 0.104 & 0.099 & 0.026 & 0.000 & $0.078 * * *$ & $0.099 * * *$ \\
\hline Ownership diff MF-Bank & -0.150 & -0.103 & 0.033 & 0.000 & $-0.117 * * *$ & $-0.103 * * *$ \\
\hline \multicolumn{7}{|l|}{ Firm characteristics: } \\
\hline Log (total assets) & 8.021 & 8.015 & 5.266 & 5.612 & $2.755^{* * *}$ & $2.403 * * *$ \\
\hline Market to book & 2.181 & 1.819 & 6.633 & 1.766 & $-4.451 * * *$ & 0.053 \\
\hline Market leverage & 0.117 & 0.092 & 0.143 & 0.083 & $-0.026^{* * *}$ & 0.009 \\
\hline Cash ratio & 0.175 & 0.120 & 0.243 & 0.136 & $-0.068 * * *$ & $-0.016 * * *$ \\
\hline Foreign sales / sales & 0.412 & 0.416 & 0.155 & 0.000 & $0.257 * * *$ & $0.416^{* * *}$ \\
\hline
\end{tabular}




\section{Table 4. Likelihood of cross-border acquisition}

The table reports the Probit model of the probability to do CBA. Dependent variable is a dummy variable equal to 1 for CBA deals, and 0 for firms that do not have CBA over the sample period. The firms that do not have CBAs include all firms that have available ownership and firm characteristic data, finance firms and regulated utilities are excluded. All variables are defined in Appendix. All regressions control for industry (based on Fama French 49 industries) and year fixed effects. Standard errors (in parentheses) are robust errors corrected for clustering of observations at the industry level. Economic significances of main variables are reported in the brackets underneath the standard errors. Economic significance is the marginal effect on the probability of CBA for a one standard deviation change for a continuous variable, holding other variables at the mean level. ***, **, and * indicate significance at the $1 \%, 5 \%$ and $10 \%$ levels, respectively.

\begin{tabular}{|c|c|c|c|c|}
\hline & (1) & (2) & (3) & (4) \\
\hline Bank Ownership & $\begin{array}{l}0.307 * * * \\
(0.092) \\
{[0.048]}\end{array}$ & & & $\begin{array}{l}0.271 * * * \\
(0.087) \\
{[0.042]}\end{array}$ \\
\hline Mutual fund ownership & & $\begin{array}{c}-0.005 \\
(0.062) \\
{[-0.001]}\end{array}$ & & $\begin{array}{c}-0.001 \\
(0.054) \\
{[-0.0002]}\end{array}$ \\
\hline Family ownership & & & $\begin{array}{l}-0.239 * * * \\
(0.091) \\
{[-0.038]}\end{array}$ & $\begin{array}{c}-0.152 * \\
(0.086) \\
{[-0.024]}\end{array}$ \\
\hline Log (total assets) & $\begin{array}{l}0.222 * * * \\
(0.014)\end{array}$ & $\begin{array}{l}0.233 \text { *** } \\
(0.013)\end{array}$ & $\begin{array}{l}0.229 * * * \\
(0.013)\end{array}$ & $\begin{array}{l}0.220 * * * \\
(0.014)\end{array}$ \\
\hline Market-to-book & $\begin{array}{l}-0.002 \\
(0.002)\end{array}$ & $\begin{array}{l}-0.002 \\
(0.002)\end{array}$ & $\begin{array}{l}-0.002 \\
(0.002)\end{array}$ & $\begin{array}{l}-0.002 \\
(0.002)\end{array}$ \\
\hline Market leverage & $\begin{array}{l}-1.226^{* * *} \\
(0.193)\end{array}$ & $\begin{array}{l}-1.296 * * * \\
(0.192)\end{array}$ & $\begin{array}{l}-1.313^{* * *} \\
(0.193)\end{array}$ & $\begin{array}{l}-1.244 * * * \\
(0.195)\end{array}$ \\
\hline Cash ratio & $\begin{array}{l}-0.518^{* *} \\
(0.241)\end{array}$ & $\begin{array}{l}-0.531 * * \\
(0.235)\end{array}$ & $\begin{array}{l}-0.524 * * \\
(0.238)\end{array}$ & $\begin{array}{l}-0.515^{* *} \\
(0.241)\end{array}$ \\
\hline Foreign sales/sales & $\begin{array}{l}0.951 * * * \\
(0.097)\end{array}$ & $\begin{array}{l}0.959 * * * \\
(0.097)\end{array}$ & $\begin{array}{l}0.957 * * * \\
(0.098)\end{array}$ & $\begin{array}{l}0.950 * * * \\
(0.097)\end{array}$ \\
\hline $\begin{array}{l}\text { Industry dummies } \\
\text { Year dummies }\end{array}$ & $\begin{array}{l}\text { Yes } \\
\text { Yes }\end{array}$ & $\begin{array}{l}\text { Yes } \\
\text { Yes }\end{array}$ & $\begin{array}{l}\text { Yes } \\
\text { Yes }\end{array}$ & $\begin{array}{l}\text { Yes } \\
\text { Yes }\end{array}$ \\
\hline $\begin{array}{l}\text { Observations } \\
\text { Pseudo R-sq }\end{array}$ & $\begin{array}{c}15,545 \\
0.290\end{array}$ & $\begin{array}{c}15,545 \\
0.288\end{array}$ & $\begin{array}{c}15,545 \\
0.288\end{array}$ & $\begin{array}{c}15,545 \\
0.290\end{array}$ \\
\hline
\end{tabular}


Table 5. Deal value of cross-border acquisitions

The table reports the regression results of the deal value of CBAs. Dependent variable is the logarithm of the deal values of CBAs in a fiscal year. Inverse Mills Ratio (IMR) is included to control for selection bias. All regressions control for industry (based on Fama French 49 industries) and year fixed effects. Variables are defined in Appendix. Standard errors (in parentheses) are robust errors corrected for clustering of observations at the industry level. ***, $* *$, and $*$ indicate significance at the $1 \%, 5 \%$ and $10 \%$ levels, respectively.

\begin{tabular}{lcccc}
\hline & $(1)$ & $(2)$ & $(3)$ & $(4)$ \\
\hline Bank Ownership & 0.070 & & & 0.003 \\
& $(0.213)$ & & & $(0.230)$ \\
Mutual fund ownership & & 0.122 & 0.045 \\
& & $(0.200)$ & $(0.234)$ \\
Family ownership & & & $-0.412^{*}$ & $-0.400^{*}$ \\
& & & $(0.208)$ & $(0.231)$ \\
Log (total assets) & $0.359^{* * *}$ & $0.367^{* * *}$ & $0.374^{* * *}$ & $0.376^{* * *}$ \\
& $(0.079)$ & $(0.079)$ & $(0.077)$ & $(0.078)$ \\
Market-to-book & 0.010 & 0.011 & 0.014 & 0.014 \\
& $(0.024)$ & $(0.023)$ & $(0.023)$ & $(0.022)$ \\
Market leverage & 0.573 & 0.522 & 0.430 & 0.424 \\
& $(0.680)$ & $(0.678)$ & $(0.657)$ & $(0.654)$ \\
Cash ratio & $0.662^{* *}$ & $0.656^{* *}$ & $0.637^{*}$ & $0.639^{*}$ \\
& $(0.320)$ & $(0.325)$ & $(0.327)$ & $(0.320)$ \\
Stock price run-up & $0.249^{*}$ & $0.252^{*}$ & $0.238^{*}$ & $0.239^{*}$ \\
& $(0.134)$ & $(0.137)$ & $(0.135)$ & $(0.139)$ \\
IMR & $-0.524^{* *}$ & $-0.514^{* *}$ & $-0.464^{*}$ & $-0.462^{*}$ \\
Industry dummies & $(0.235)$ & $(0.235)$ & $(0.237)$ & $(0.237)$ \\
Year dummies & Yes & Yes & Yes & Yes \\
Observations & Yes & Yes & Yes & Yes \\
Pseudo R-sq & 1,034 & 1,034 & 1,034 & 1,034 \\
& 0.323 & 0.324 & 0.325 & 0.324 \\
\hline
\end{tabular}


Table 6. Change of ownership: Voting with feet

Dependent variables are the change of block ownership from the year immediately before the merger announcement to the year after the announcement (columns (1) and (3)), and the change of the number of blockholders over the same time frame (columns (2) and (4)). All regressions control for selection bias, industry (based on Fama French 49 industries), year and country fixed effects. Variables are defined in Appendix. Standard errors (in parentheses) are robust errors corrected for clustering of observations at the industry level. ***,**, and * indicate significance at the $1 \%, 5 \%$ and $10 \%$ levels, respectively.

\begin{tabular}{|c|c|c|c|c|}
\hline & (1) & (2) & (3) & (4) \\
\hline Dependent variable: & $\begin{array}{c}\Delta \text { Bank } \\
\text { Ownership }\end{array}$ & $\begin{array}{l}\Delta \text { No. Bank } \\
\text { blockholders }\end{array}$ & $\begin{array}{l}\Delta \text { Mutual Fund } \\
\text { Ownership }\end{array}$ & $\begin{array}{c}\Delta \text { No. Mutual Fund } \\
\text { blockholders }\end{array}$ \\
\hline Family ownership & $\begin{array}{l}-0.028 \\
(0.036)\end{array}$ & $\begin{array}{l}-0.101 \\
(0.133)\end{array}$ & $\begin{array}{l}-0.051 * * * \\
(0.017)\end{array}$ & $\begin{array}{l}-0.307 * * * \\
(0.091)\end{array}$ \\
\hline Bank ownership & $\begin{array}{l}-0.399 * * * \\
(0.017)\end{array}$ & $\begin{array}{l}-0.597 * * * \\
(0.078)\end{array}$ & $\begin{array}{l}-0.004 \\
(0.016)\end{array}$ & $\begin{array}{l}-0.035 \\
(0.073)\end{array}$ \\
\hline Mutual Fund ownership & $\begin{array}{c}0.001 \\
(0.025)\end{array}$ & $\begin{array}{l}0.173 * * \\
(0.080)\end{array}$ & $\begin{array}{l}-0.385^{* * *} \\
(0.027)\end{array}$ & $\begin{array}{l}-1.201 * * * \\
(0.166)\end{array}$ \\
\hline Log (total assets) & $\begin{array}{c}0.008 \\
(0.006)\end{array}$ & $\begin{array}{c}0.009 \\
(0.028)\end{array}$ & $\begin{array}{l}-0.001 \\
(0.005)\end{array}$ & $\begin{array}{l}-0.001 \\
(0.025)\end{array}$ \\
\hline Market-to-book & $\begin{array}{l}-0.003 \\
(0.003)\end{array}$ & $\begin{array}{c}0.021 \\
(0.020)\end{array}$ & $\begin{array}{l}-0.001 \\
(0.002)\end{array}$ & $\begin{array}{c}0.005 \\
(0.017)\end{array}$ \\
\hline Market leverage & $\begin{array}{l}-0.006 \\
(0.058)\end{array}$ & $\begin{array}{l}0.011 \\
(0.229)\end{array}$ & $\begin{array}{c}0.017 \\
(0.041)\end{array}$ & $\begin{array}{c}0.282 \\
(0.252)\end{array}$ \\
\hline Cash ratio & $\begin{array}{c}0.029 \\
(0.033)\end{array}$ & $\begin{array}{l}-0.014 \\
(0.093)\end{array}$ & $\begin{array}{l}-0.036 \\
(0.034)\end{array}$ & $\begin{array}{c}0.049 \\
(0.164)\end{array}$ \\
\hline Diversifying deal dummy & $\begin{array}{l}0.016 * * \\
(0.005)\end{array}$ & $\begin{array}{r}0.071 * \\
(0.036)\end{array}$ & $\begin{array}{l}-0.011 \\
(0.008)\end{array}$ & $\begin{array}{l}-0.058 \\
(0.056)\end{array}$ \\
\hline Cash pay dummy & $\begin{array}{c}0.007 \\
(0.006)\end{array}$ & $\begin{array}{c}0.071 \\
(0.045)\end{array}$ & $\begin{array}{l}-0.002 \\
(0.008)\end{array}$ & $\begin{array}{c}0.030 \\
(0.047)\end{array}$ \\
\hline Stock pay dummy & $\begin{array}{l}-0.055^{* * *} \\
(0.023)\end{array}$ & $\begin{array}{c}0.029 \\
(0.154)\end{array}$ & $\begin{array}{l}-0.022 \\
(0.023)\end{array}$ & $\begin{array}{l}-0.160 \\
(0.148)\end{array}$ \\
\hline Unlisted dummy & $\begin{array}{l}-0.014 \\
(0.022)\end{array}$ & $\begin{array}{l}-0.048 \\
(0.078)\end{array}$ & $\begin{array}{c}0.001 \\
(0.008)\end{array}$ & $\begin{array}{c}0.022 \\
(0.076)\end{array}$ \\
\hline Stock price run-up & $\begin{array}{l}-0.016 \\
(0.017)\end{array}$ & $\begin{array}{c}0.045 \\
(0.114)\end{array}$ & $\begin{array}{l}-0.005 \\
(0.016)\end{array}$ & $\begin{array}{l}-0.021 \\
(0.065)\end{array}$ \\
\hline IMR & $\begin{array}{l}-0.005 \\
(0.025)\end{array}$ & $\begin{array}{l}-0.077 \\
(0.112)\end{array}$ & $\begin{array}{c}0.039 * \\
(0.021)\end{array}$ & $\begin{array}{c}0.174 \\
(0.149)\end{array}$ \\
\hline Industry dummies & Yes & Yes & Yes & Yes \\
\hline Year dummies & Yes & Yes & Yes & Yes \\
\hline Country dummies & Yes & Yes & Yes & Yes \\
\hline Observations & 2,544 & 2,544 & 2,544 & 2,544 \\
\hline Adj. R-sq & 0.293 & 0.096 & 0.217 & 0.091 \\
\hline
\end{tabular}


Table 7. Effect of the balance of power among blockholders on CBA shareholder value

Dependent variable is the market model adjusted three-day CARs over days [-1, +1], where day 0 is the announcement date. The market model parameters are estimated over the period $(-210,-11)$ using the CRSP value-weighted return as the market index. Dummy variables DLow Bank-Family $_{\text {equals one if Ownership diff }}$ Bank-family $<$ $-5 \%$, DHigh $_{\text {Bank-Family }}$ equals one if Ownership diff $f_{\text {Bank-family }}>5 \%$; and zero otherwise. Dummy variables $D L o w_{M F-}$ Family equals one if Ownership diff MF-family $_{3}<-5 \%$, DHigh MF-Family equals one if Ownership diff $_{M F-f a m i l y}>5 \%$; and zero otherwise. Note the left-out group is the ownership difference within $\pm 5 \%$. All other variables are defined in Appendix. All regressions control for selection bias (IMR), industry (based on Fama French 49 industries), year, and country fixed effects. Standard errors (in parentheses) are robust errors corrected for clustering of observations at the industry level. $* * *, * *$, and $*$ indicate significance at the $1 \%, 5 \%$ and $10 \%$ levels, respectively.

\begin{tabular}{|c|c|c|c|}
\hline & (1) & (2) & (3) \\
\hline DLow $_{\text {Bank-Family }}$ & $\begin{array}{l}-0.184 \\
(0.359)\end{array}$ & & $\begin{array}{c}0.227 \\
(0.557)\end{array}$ \\
\hline DHigh $_{\text {Bank-Family }}$ & $\begin{array}{l}-0.063 \\
(0.287)\end{array}$ & & $\begin{array}{l}-0.038 \\
(0.285)\end{array}$ \\
\hline DLow $_{\text {MF-Family }}$ & & $\begin{array}{l}-0.682 * * \\
(0.262)\end{array}$ & $\begin{array}{l}-0.854 * \\
(0.453)\end{array}$ \\
\hline DHigh $_{\text {MF-Family }}$ & & $\begin{array}{l}-0.483 * * \\
(0.189)\end{array}$ & $\begin{array}{l}-0.475^{* *} \\
(0.192)\end{array}$ \\
\hline Log (total assets) & $\begin{array}{l}-0.172 * * \\
(0.068)\end{array}$ & $\begin{array}{l}-0.209 * * * \\
(0.072)\end{array}$ & $\begin{array}{l}-0.207 * * * \\
(0.072)\end{array}$ \\
\hline Market-to-book & $\begin{array}{l}-0.009 \\
(0.117)\end{array}$ & $\begin{array}{l}-0.016 \\
(0.118)\end{array}$ & $\begin{array}{l}-0.018 \\
(0.116)\end{array}$ \\
\hline Market leverage & & $\begin{array}{l}-1.727 \\
(1.259)\end{array}$ & $\begin{array}{l}-1.748 \\
(1.310)\end{array}$ \\
\hline Cash ratio & $\begin{array}{c}0.234 \\
(0.919)\end{array}$ & $\begin{array}{c}0.257 \\
(0.893)\end{array}$ & $\begin{array}{c}0.255 \\
(0.888)\end{array}$ \\
\hline Diversifying deal dummy & $\begin{array}{c}0.188 \\
(0.177)\end{array}$ & $\begin{array}{c}0.189 \\
(0.170)\end{array}$ & $\begin{array}{c}0.196 \\
(0.168)\end{array}$ \\
\hline Cash pay dummy & $\begin{array}{l}0.550 * * \\
(0.263)\end{array}$ & $\begin{array}{l}0.548 * * \\
(0.269)\end{array}$ & $\begin{array}{l}0.550^{* *} \\
(0.264)\end{array}$ \\
\hline Stock pay dummy & $\begin{array}{c}1.654 \\
(1.134)\end{array}$ & $\begin{array}{c}1.674 \\
(1.135)\end{array}$ & $\begin{array}{c}1.665 \\
(1.138)\end{array}$ \\
\hline Unlisted dummy & $\begin{array}{l}-0.625 \\
(0.474)\end{array}$ & $\begin{array}{l}-0.603 \\
(0.471)\end{array}$ & $\begin{array}{l}-0.609 \\
(0.467)\end{array}$ \\
\hline Stock price run-up & $\begin{array}{l}-0.889 \\
(0.567)\end{array}$ & $\begin{array}{l}-0.922 \\
(0.556)\end{array}$ & $\begin{array}{l}-0.920 \\
(0.566)\end{array}$ \\
\hline IMR & $\begin{array}{l}-0.185 \\
(0.475)\end{array}$ & $\begin{array}{l}-0.224 \\
(0.469)\end{array}$ & $\begin{array}{l}-0.249 \\
(0.493)\end{array}$ \\
\hline Industry dummies & Yes & Yes & Yes \\
\hline Year dummies & Yes & Yes & Yes \\
\hline Country dummies & Yes & Yes & Yes \\
\hline
\end{tabular}


Observations Adj. R-sq
2,568

0.021
2,568

0.024

2,568

0.024 


\section{Figure 1. Empirical Results on the Relationship between CARs and Blockholding Differences}

We stratify the sample into 3 groups based on some critical cutoffs of the ownership difference: ownership difference less than $-5 \%$, between $-5 \%$ and $5 \%$, and greater than $5 \%$. This figure plots the mean CAR of each group (Y axis) versus the mean ownership differences of each group (X axis). The solid line represents the relation of CAR and ownership difference between mutual fund and family blockholding; and the dotted line represent the relation of CAR and ownership difference between bank and family blockholding.

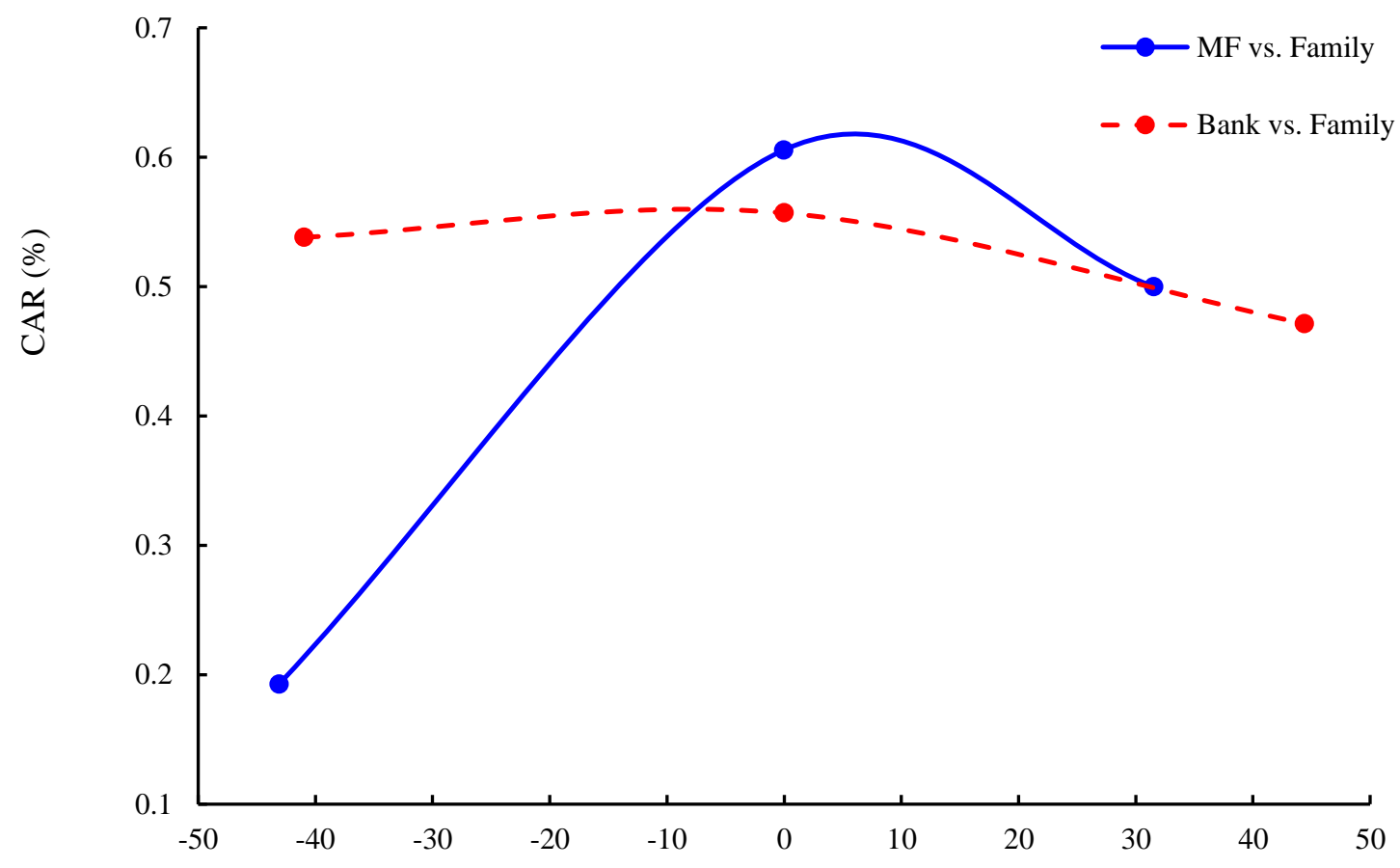

Banks or Mutual funds ownership - Family ownership (\%) 


\section{Blockholder Heterogeneity and Conflicts in Cross-border Acquisitions}

\section{Highlights}

- Family, bank, and mutual fund blockholders are heterogeneous in their relations to an acquirer's cross-border acquisition (CBA) decision and outcomes.

- When faced with principal-principal (PP) conflicts with family blockholders, mutual funds may exit after a CBA announcement; whereas, such actions by banks are relatively insignificant.

- Under equal voting power, the family and mutual fund blockholders may be more motivated to monitor each other and jointly discipline the management, leading to greater shareholder value; whereas, such effects of the power balance between the family and banks are relatively insignificant. 